\title{
Variability in the Mechanical Properties of Commercially Available Thermally Modified Hardwood Lumber
}

\author{
Juan J. Gonzalez,* Brian Bond, and Henry Quesada \\ Research indicates that users of thermally modified wood lack information \\ regarding the improved performance and any variations that may exist for \\ the "same" product when manufactured by different companies. The goal \\ of this study was to evaluate the variability in mechanical properties of \\ three thermally modified hardwoods and determine the variability between \\ three different manufacturers. To determine the hardness, bending \\ (modulus of elasticity and module of rupture) and shrinkage values, testing \\ was conducted following ASTM standard D143. The samples were \\ conditioned at $20^{\circ} \mathrm{C}$ and a relative humidity of $65 \%$ until they reached an \\ equilibrium moisture content before testing. Analysis of variance was used \\ to determine the variability within and between the different processes \\ used by each company. Seven out of 18 (39\%) tests indicated that there \\ were statistical differences regarding the mechanical performances of the \\ wood samples. Yellow poplar had the least variation between companies \\ (only difference in equilibrium moisture content, EMC) and red maple had \\ the most (hardness, tangential shrinkage, and EMC). While the means for \\ these properties were statistically different, the differences in application \\ for hardness and EMC are slight. For example, the largest difference \\ between processes in hardness was $83.6 \mathrm{~kg}$, for tangential shrinkage, \\ $0.45 \%$ and $1.37 \%$ for EMC. These differences are suggested to be \\ inconsequential when compared to the values that exist between different \\ species of untreated wood.
}

Keywords: Thermally modified lumber; ANOVA; Yellow poplar; Red maple; White Ash; Mechanical properties; ASTM D143

Contact information: Brooks Forest Products Center, 1650 Research Center Drive, Blacksburg, VA 24060 USA; * Corresponding author: jjgoco02@vt.edu

\section{INTRODUCTION}

One of the innovative products that has gained attention in the U.S. lumber market is thermally modified (TM) lumber, which has a large variety of exterior and interior uses including the following: musical instruments, guns stocks, decking applications, outdoor and indoor furniture, siding, roofing, door and window frames, and flooring. Thermally modified wood (TMW) has been available since the early 1990s in Europe, where it was developed as an alternative to tropical hardwoods and preservative treated wood for exterior applications. Tropical hardwoods are in high demand for furniture applications, with inelastic prices (Odoom 2001); they provide an alternative to chemically treated wood and are attractive due to regulations in place to reduce the use of toxic substances. Thermally modified wood products provide opportunities for the use of low-value timber, due to their increased performance against biological organisms and increased dimensional stability, potentially increasing the value of public and private lands with low-value wood, i.e., lower value species, quality, and size (Baynes et al. 2014). 
Thermally modified wood products have been available in the United States since 2004 when Westwood Corp started exhibiting thermally-treated wood products at fairs, and companies such as Jartek Inc. and Stellac Inc also started exhibiting TMW products (Sandberg and Kutnar 2016). By 2012, Canada and the United States had seven and ten manufacturers of TMW, respectively.

The adoption of TMW has had limited success according to Donahue and Winandy (2014), which is showcased by the low production levels reported by the United Nations Economic Commission for Europe (UNECE) and the Food and Agriculture Organization (FAO) (2013) in the Forest Products Annual Market review. These sources indicate that the volume production of TMW between 2012 and 2013 was around 315,000 $\mathrm{m}^{3}$ in Europe and $100,000 \mathrm{~m}^{3}$ in the United States. This was the last report from the Forest Products Annual Market review containing this information, since consumers and producers were hesitant to provide updated information.

Thermal modification is a great way to increase some of the physical performance characteristics of wood, e.g., the durability against fungi, which is increased due to the degradation of hemicelluloses found in the wood, e.g., sugars (Alen et al. 2012; Wardell 2015). Thermally modified wood products, such as decking, are competitively priced in comparison to traditional premium decking or tropical species such as Ipe wood. However, the current market for TMW in the U.S. is still hesitant to try this product (Gamache 2017), as more than three-fifths of the professional users of decking materials were not familiar with TMW products. Potential consumers still know little about the advantages and disadvantages of TMW, and there is an additional concern about the possible decrease in mechanical strength (Wang et al. 2012). Although there is some general knowledge that TMW could be more resistant to water absorption and have an increased resistance to decay, there is still no national or international consensus on TMW standards (Sandberg and Kutnar 2016; and Schnabel et al. 2007). Europe has technical specifications for spruce and pine, as shown in "DS/CEN/TS 15679 Thermally Modified Timber - Definitions and Characteristics". Additionally, in Europe TMW has a certificate for "Quality Mark TMT", certifying that the product conforms to the requirements of EN ISO/IEC 17067, which is specified by wood species, occasionally grading, manufacturers, and types of treatments. It is also certified with the "DIN 68800 Wood Preservation". (CEN, 2007; EPH, 2015 and Willeitner 2012). The development of standards would provide safety and reliability and raise the confidence of users, which typically leads to market share expansion.

The mechanical properties (hardness, static bending, dimensional stability, and equilibrium moisture content, EMC) of TMW tend to vary based on the schedule used for modification. These schedules are the combination of treatment temperatures and treatment times, and atmosphere inside the kiln (air or nitrogen), which are different for each species (Esteves and Pereira 2008). Most of the samples had thickness of 1 inch. Thermally modified wood can be produced using a closed or open drying system. The way an open system works is that chamber decreases the moisture content in the chamber to $0 \%$ and then the system reinjects steam to condition the wood to a moisture content of $2 \%$. A closed system maintains the steam in the chamber, creating additional pressure in the chamber (Ghiassi and Lourenço 2018). Figure 1 shows the differences in the process when working a closed system and an open system. During the thermal process, heat removes various organic compounds and changes the cellular structure, limiting the ability of the wood to absorb water (Sandberg and Kutnar 2016). 


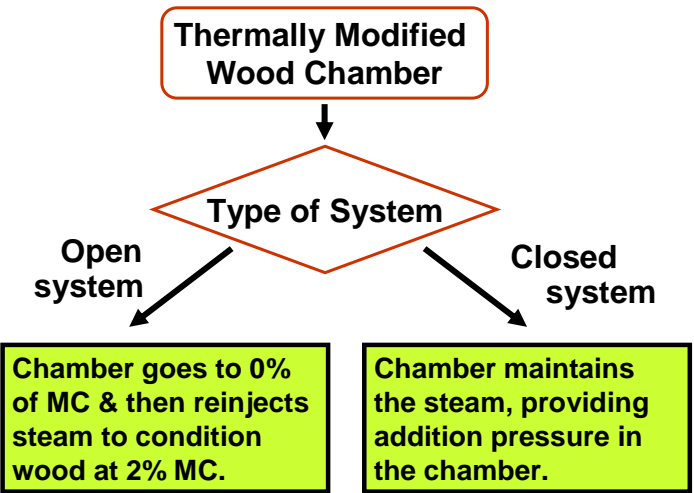

Fig. 1. Difference between open system and closed system (Ghiassi and Lourenço 2018)

Performance metrics, e.g., splitting, EMC, shrinkage and swelling, and water absorption show decreasing trends depending on the level of treatment (temperature levels and exposure times). Other properties, e.g., durability, surface hardness, bending, and modulus of elasticity, increased under certain treatment conditions but decreased under others (Esteves and Pereira 2008).

The goal of this work was to evaluate the variability in mechanical properties of TMW made from yellow poplar (Liriodendron tulipifera), red maple (Acer rubrum), and white ash (Fraxinus americana), and determine the variability in certain mechanical properties between three commercial producers of these species.

\section{EXPERIMENTAL}

\section{Methodology}

The purpose of this evaluation was to determine variability in mechanical performance for TMW produced by the three companies. Three different TMW species were provided from three companies (sources) to measure their mechanical performance. ASTM procedures (ASTM D143 2014; ASTM D4442 2016; ASTM D49336 2016) were followed to conduct each mechanical test (hardness, static bending, EMC, and dimensional stability).

Each source used a different commercial system to thermally modify their wood. Company 1 used an open system, while company 2 used a closed system during their modification process. Company 3 was the only manufacturer that used both closed and open systems and, according to the experts in the company, obtained better results from a closed system. The samples provided by company 3 were modified with a closed system. The schedules used for these samples were not provided by the company for proprietary reasons.

The sample size was limited to 14 treated samples per species from each company, since the materials for each species were donated. The samples provided by each company were 1 inch thick. Each company donated a total of 42 samples for a total of 126 samples tested. Specimens for each specific test were prepared from different individual boards to increase reliability. The companies provided random samples selected from a single production batch, but were not able provide untreated samples, so there were no control 
values to compare the performance of the TMW. However, for the species tested, the average mechanical properties are well known (Hill 2007).

Once the specimens were cut to the dimensions required by each standard, the samples were stored in a temperature and humidity-controlled room with the conditions set to a temperature of $23{ }^{\circ} \mathrm{C} \pm 2{ }^{\circ} \mathrm{C}$ and a relative humidity $(\mathrm{RH})$ of $67 \% \pm 1 \%$. Each specimen was weighed each week. Once the weight of each specimen became constant over time, the sample was determined to have reached the equilibrium of moisture content and was ready to be tested. All samples' weight was consistent over the weeks or the weight was increasing no more than 0.01 pounds.

\section{Hardness Testing Using ASTM Standard D143 (Modified)}

Hardness is defined as the resistance of wood to indentation using a $25.4 \mathrm{~mm}$ ball, also known as the Janka hardness test, and it was measured using the ASTM standard D143 (2014). All specimens were weighed before and after testing. To determine how the thermal modification effected the performance of the surface hardness by using ASTM standard D143 (2014) testing methods, the specimens were cut to dimensions of 1 in by 2 in by 6 in ( $50.8 \mathrm{~mm}$ by $50.8 \mathrm{~mm}$ by $152.4 \mathrm{~mm}$ ). The test used a ball of 0.444 inches in diameter, with a projected area of the ball on the test specimen of $1 \mathrm{~cm}^{2}$, with two penetrations on the tangential surface.

\section{Static Bending (MOE, MOR) Testing Using ASTM Standard ASTM D143}

ASTM standard D143 (2014) was used to measure the performance of the TMW in terms of static bending, with a specimen size of 1 in by 1 in by 16 in $(25 \mathrm{~mm}$ by $25 \mathrm{~mm}$ by $410 \mathrm{~mm}$ ). The load-deflection curves were recorded, and the testing was finished after the maximum load was reached for all static bending tests.

\section{Radial and Tangential Shrinkage Testing Using ASTM Standard D143 (Modified)}

ASTM standard D143 (2014) was used to determine the dimensional stability performance by estimating the radial and tangential shrinkage. The specimen size was modified to dimensions of 0.75 in by 0.75 in by 1 in $(19 \mathrm{~mm}$ by $19 \mathrm{~mm}$ by $25 \mathrm{~mm})$, due to dimensional limitations by the lumber provided.

The specimens were weighed, and their length was measured before undergoing oven drying. The oven was set to a temperature of $103{ }^{\circ} \mathrm{C} \pm 2{ }^{\circ} \mathrm{C}$ until a constant mass was reached. Once the specimens reached a constant mass, their weight and length were measured again.

\section{Equilibrium of Moisture Content (EMC) Testing Using ASTM Standard D4933}

ASTM standard D4933 (2016) was used to precisely estimate the equilibrium of moisture content (EMC) of each treatment, company, and species. The size of each specimen was $19 \mathrm{~mm}$ by $25 \mathrm{~mm}$ by $19 \mathrm{~mm}$. The first step was to condition the samples until they reached a constant mass under the following conditions: a temperature of $21{ }^{\circ} \mathrm{C}$ and a RH of $65 \%$. Periodic weighing was performed to record the mass changes and make sure the mass was constant over time. Then the samples were oven-dried at a temperature of $103{ }^{\circ} \mathrm{C}$ for at least $2 \mathrm{~d}$, until a constant mass was reached, and the mass was recorded to estimate the EMC percentage of each sample. 


\section{RESULTS AND DISCUSSION}

A normality test was conducted before an analysis comparing the statistical differences between companies was conducted. For the data that did not fit the normal distribution, instead of an ANOVA, a non-parametric test, i.e., a Kruskal-Wallis test, was conducted. The results of the normality test compared to an alpha of 0.05 are shown in Table 1.

Table 1. Normality Test for Each Species

\begin{tabular}{|c|c|c|c|}
\hline Species & Test & $p$-value & $\begin{array}{c}\text { Normal } \\
\text { Distribution }\end{array}$ \\
\hline Yellow poplar & Modulus of elasticity & 0.862 & Yes \\
\hline Yellow poplar & Modulus of rupture & 0.315 & Yes \\
\hline Yellow poplar & Hardness & 0.374 & Yes \\
\hline Yellow poplar & Radial shrinkage & 0.893 & Yes \\
\hline Yellow poplar & Tangential shrinkage & 0.234 & Yes \\
\hline Yellow poplar & Equilibrium of moisture content & 0.893 & Yes \\
\hline Red maple & Modulus of elasticity & 0.292 & Yes \\
\hline Red maple & Modulus of rupture & 0.007 & No \\
\hline Red maple & Hardness & 0.356 & Yes \\
\hline Red maple & Radial Shrinkage & 0.006 & No \\
\hline Red maple & Tangential Shrinkage & 0.005 & No \\
\hline Red maple & Equilibrium of moisture content & 0.080 & Yes \\
\hline Ash & Modulus of elasticity & 0.649 & Yes \\
\hline Ash & Modulus of rupture & 0.231 & Yes \\
\hline Ash & Hardness & 0.799 & Yes \\
\hline Ash & Radial Shrinkage & 0.000 & No \\
\hline Ash & Tangential Shrinkage & 0.280 & Yes \\
\hline Ash & Equilibrium of moisture content & 0.085 & Yes \\
\hline
\end{tabular}

While the focus of this work was to evaluate the differences in the properties between the commercial systems, a comparison of the author's results to the untreated values from literature also added insight into the potential improvements that these processes provide.

\section{Modulus of Elasticity (MOE)}

There were significant differences in the MOEs between the three commercial processes for white ash, as shown in Table 2.

Table 2. Modulus of Elasticity Results

\begin{tabular}{|c|c|c|}
\hline Test & Species & $p$-value \\
\hline MOE & Yellow poplar & 0.762 \\
\hline MOE & Red maple & 0.140 \\
\hline MOE & Ash & 0.002 \\
\hline
\end{tabular}

A graphical representation of the means and standard deviation for the ash samples is shown in Fig. 2, where the bar plot shows that the mean value from company 1 was higher than the other two companies, and that the mean values between company 1 and 
company 3 were the same. An explanation for this behavior could be related to company 1 using a different system, i.e., an open system, to thermally treat the wood, whereas company 2 and company 3 both used a closed system. However, it should be noted that all companies used different schedules for their thermal modification process. For MOE, an open system showed better performance in comparison to a closed system.

Boonstra et al. (2007) suggest that the increases in MOE due to thermal modification is related to the "degradation of the hemicelluloses, disrupting the loadsharing capacity of the lignin-hemicelluloses matrix, and increase of the relative amount of crystalline cellulose." They also suggest that increased cross linking of the lignin network increased the rigid structure around the cellulose microfibrils/fibrils and improves the strength of the middle lamella.

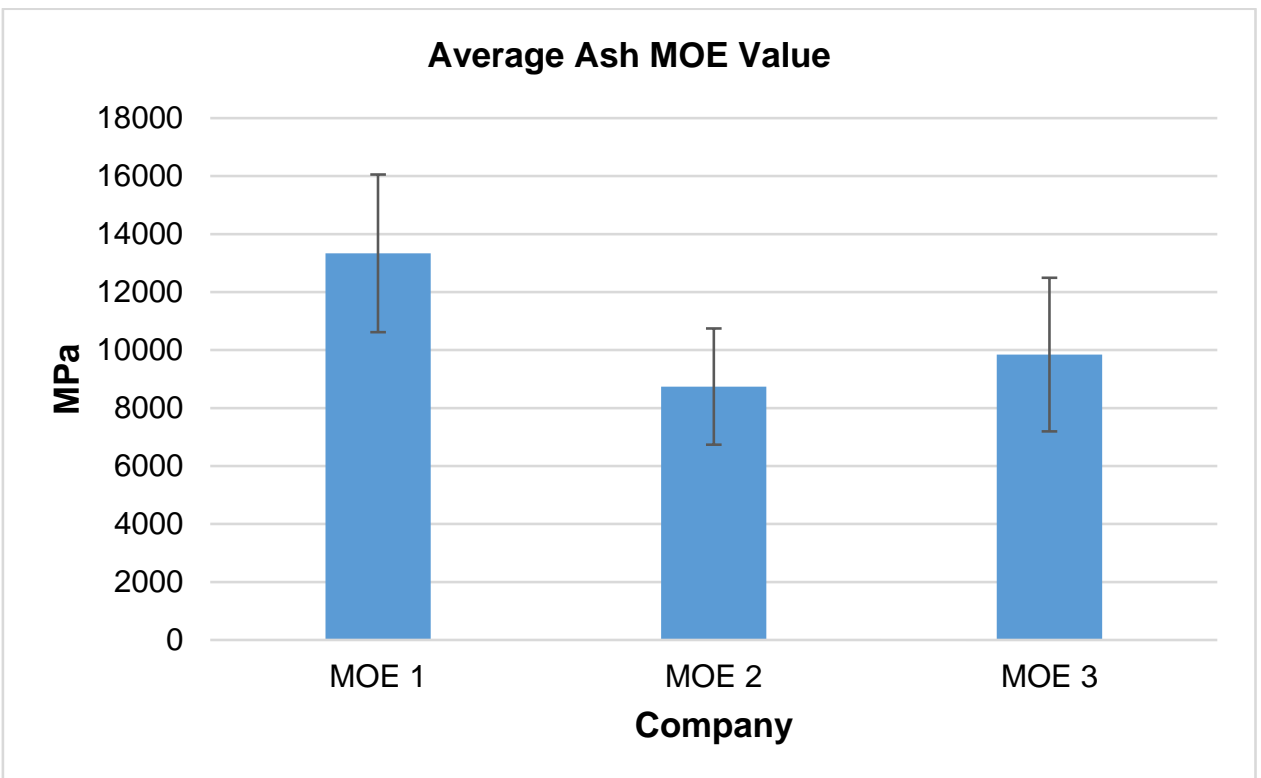

Fig. 2. Average and Standard Deviation for Ash MOE Values for the product of each company.

Table 3. Descriptive Statistics for the MOE Test Results

\begin{tabular}{|c|c|c|c|c|c|c|}
\hline Company & Species & Test & Mean (MPa) & Std. Dev. & Coef. Var. & Median (MPa) \\
\hline 1 & Yellow poplar & MOE & 12502 & 2287 & 18.30 & 12710 \\
\hline 2 & Yellow poplar & MOE & 12868 & 2260 & 17.56 & 12885 \\
\hline 3 & Yellow poplar & MOE & 12229 & 2323 & 19.00 & 12025 \\
\hline 1 & Red maple & MOE & 13260 & 874 & 6.59 & 13271 \\
\hline 2 & Red maple & MOE & 13058 & 1366 & 10.46 & 13376 \\
\hline 3 & Red maple & MOE & 14646 & 1022 & 6.98 & 14727 \\
\hline 1 & Ash & MOE & $13336(\mathrm{~A})$ & 2719 & 20.39 & 13971 \\
\hline 2 & Ash & MOE & $8740(B)$ & 2004 & 22.93 & 9336 \\
\hline 3 & Ash & MOE & $9844(B)$ & 2649 & 26.91 & 10118 \\
\hline
\end{tabular}

The average MOE values for the TM yellow poplar samples from the three companies were higher than the value reported for untreated materials (10900 MPa) (Hill 2007). The TMW samples showed a performance increase of $14 \%, 17 \%$, and $12 \%$ for 
company 1 , company 2 , and company 3 , respectively. A similar trend occurred with red maple, where the MOE value for the untreated red maple lumber was $11300 \mathrm{MPa}$ (Hill 2007). The ash values from company 1 , company 2 , and company 3 showed an incremental performance increase of $16 \%, 19 \%$, and $26 \%$, respectively. Ash was the only species to show a different trend, where the samples from company 2 and company 3 had a $31 \%$ and $20 \%$ lower MOE than untreated ash (12000 MPa) (Hill 2007). However, Company 1 had an $11 \%$ increase in MOE compared to the untreated MOE value. The difference in MOE performance for ash could be related to species and schedule differences, as suggested by Esteves and Pereira (2008). However, this seems unlikely, given the same behavior was not noticed for yellow poplar or red maple. Another factor to consider is that company 1 used an open system to treat their lumber, while company 2 used a closed system, and company 3 used both systems. The expected outcome for all three species was an increase in MOE as suggested by Donahue et al. (2011), who reported a slight increase in MOE (from $11100 \mathrm{MPa}$ to $12258 \mathrm{MPa}$ ) for yellow poplar that was thermally modified using the ThermoWood ${ }^{\circledR}$ treatment. The coefficient of variation shown was highest for ash, indicating that there was a greater level of dispersion around the mean. This was likely due to the small sample size and/or high variability within the process.

\section{Modulus of Rupture (MOR)}

No significant differences in the MOR values were found between the three companies, indicating that the different systems and schedules used in thermal modification did not affect the MOR performance. Table 4 shows the results obtained from the MOR testing for the three species studied.

Table 4. Modulus of Rupture Results

\begin{tabular}{|c|c|c|}
\hline Test & Species & $p$-value \\
\hline MOR & Yellow poplar & 0.164 \\
\hline MOR & Red maple & $0.258^{*}$ \\
\hline MOR & Ash & 0.124 \\
\hline $\begin{array}{l}\text { Note: an asterisk }\left(^{*}\right) \text { means that the data was not normally distributed, and a Kruskal-Wallis } \\
\text { test was conducted instead. }\end{array}$
\end{tabular}

The standard deviation, the mean, and median values for each company are displayed in Table 5. The mean values obtained from the tests conducted showed that for yellow poplar the values were between 64.3 and 81.2 MPa, for red maple the values were between 75.7 and $88.87 \mathrm{MPa}$ and for ash the values were between 49.5 and $68.2 \mathrm{MPa}$. Results from Adewopo and Patterson (2011) gave mean values between 107.6 and 140.5 $\mathrm{MPa}$ for red oak, and between 81.5 and $110.7 \mathrm{MPa}$ for sweetgum, showcasing a higher performance for these species compared to the three species treated in this study. The species treated by Adewopo and Patterson (2011) used the following conditions: a treatment temperature between $93{ }^{\circ} \mathrm{C}$ and $204{ }^{\circ} \mathrm{C}$ and a treatment duration between $2 \mathrm{~h}$ to $8 \mathrm{~h}$. These conditions could have contributed to the better performance obtained by Adewopo and Patterson (2011), when compared to the species in this study. 
Table 5. Descriptive Statistics for the MOR Test Results

\begin{tabular}{|c|c|c|c|c|c|c|}
\hline Company & Species & Test & Mean (MPa) & Std. Dev. & Coef. Var. & Median (MPa) \\
\hline 1 & Yellow poplar & MOR & 77.09 & 26.13 & 33.89 & 80.34 \\
\hline 2 & Yellow poplar & MOR & 81.2 & 18.63 & 22.94 & 83.68 \\
\hline 3 & Yellow poplar & MOR & 64.27 & 26.49 & 41.22 & 65.78 \\
\hline 1 & Red maple & MOR & 75.71 & 25.82 & 34.11 & 81.79 \\
\hline 2 & Red maple & MOR & 88.87 & 21.64 & 24.35 & 93.03 \\
\hline 3 & Red maple & MOR & 79.54 & 22.58 & 28.39 & 87.43 \\
\hline 1 & Ash & MOR & 49.53 & 18.33 & 37.02 & 54.35 \\
\hline 2 & Ash & MOR & 68.17 & 18.04 & 26.47 & 67.10 \\
\hline 3 & Ash & MOR & 56.97 & 19.83 & 34.80 & 55.33 \\
\hline
\end{tabular}

The MOR values for the TM yellow poplar from company 1 and company 2 were higher (10\% and $15 \%$, respectively) than the MOR values for unmodified wood reported by Hill (2007) (69.7 MPa). However, the MOR value for company 3 was $8 \%$ lower than the value reported by Hill (2007). The TM red maple samples from all three companies had lower values than that the values reported for unmodified wood (92.0 MPa) (Hall, 2007). The average MOR value for company 1, company 2, and company 3 showed a decrease in performance of $19 \%, 4 \%$, and $15 \%$, respectively. A similar trend occurred with ash, where the obtained MOR value for untreated ash (Hill 2007) was $103.0 \mathrm{MPa}$, and the values from company 1 , company 2 , and company 3 , were $70 \%, 41 \%$ and $58 \%$ less, respectively. The coefficient of variance showed higher values for every test that was perform, which is expected since the samples showed different levels of resistance to fail, this resulted on having values that are not similar and high dispersion.

The author's results were similar to those obtained by Donahue et al. (2011) for yellow poplar, who reported a slight decrease in performance for MOR, from $103 \mathrm{MPa}$ to $97 \mathrm{MPa}$. The average values reported by Donahue et al. (2011) were also higher than the values obtained by the authors. Literature suggests that thermal modification can result either an increase (Donahue et al. 2011; Esteves and Pereira 2009) or a decrease (Stamm et al. 1946; Bengtsson et al. 2002; Esteves and Pereira 2009) in MOR and given the mixed results between species for this work, the authors hypothesize that the differences noted were due to the different schedules used by each company for each species.

\section{Hardness}

There was no significant difference in the hardness values for the different companies for both the yellow poplar and ash samples (as shown in Table 6).

Table 6. The $p$-values for Yellow Poplar, Red Maple, and Ash Samples

\begin{tabular}{|c|c|c|}
\hline Test & Species & $p$-value \\
\hline Hardness & Yellow Poplar & 0.324 \\
\hline Hardness & Red Maple & 0.007 \\
\hline Hardness & Ash & 0.565 \\
\hline
\end{tabular}


The red maple samples showed a statistical difference between the average hardness values for the three companies, which indicated that the system used, or the schedule, influenced the hardness. The results of the Tukey test are presented in Fig. 3, where the plot shows that company 2 had higher hardness values in comparison to company $1(18 \%)$ and company $3(12 \%)$ and the mean values were similar between company 1 and company 3 .

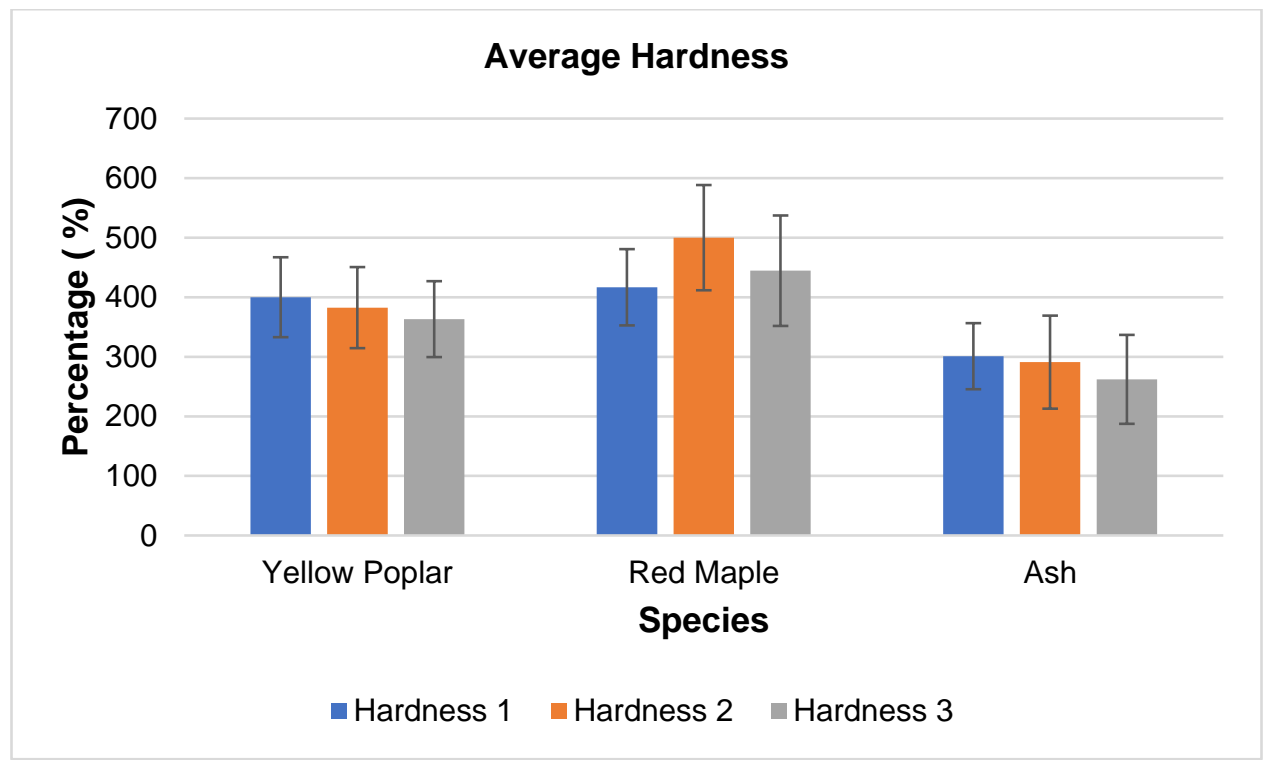

Fig. 3. Average and standard deviation for the hardness values

The descriptive statistics from the hardness tests (Table 7), indicated that the red maple hardness values for the company 1 and company 2 were lower than the mean hardness values for company 3 samples, and even with high standard deviation values.

Table 7. Descriptive Statistics for the Hardness Test Results

\begin{tabular}{|c|c|c|c|c|c|c|}
\hline Company & Species & Test & Mean $(\mathrm{kg})$ & Std. Dev. & Coef. Var. & Median (kg) \\
\hline 1 & Yellow poplar & Hardness & 291.02 & 78.11 & 26.85 & 266.94 \\
\hline 2 & Yellow poplar & Hardness & 301.00 & 55.43 & 18.42 & 295.15 \\
\hline 3 & Yellow poplar & Hardness & 262.13 & 74.66 & 28.48 & 248.93 \\
\hline 1 & Red maple & Hardness & $416.76(\mathrm{~A})$ & 67.09 & 16.10 & 425.02 \\
\hline 2 & Red maple & Hardness & $500.04(\mathrm{~B})$ & 68.08 & 13.61 & 486.25 \\
\hline 3 & Red maple & Hardness & $444.52(\mathrm{~B})$ & 63.73 & 14.34 & 430.82 \\
\hline 1 & Ash & Hardness & 382.56 & 88.36 & 23.09 & 400.07 \\
\hline 2 & Ash & Hardness & 400.02 & 64.05 & 16.01 & 386.82 \\
\hline 3 & Ash & Hardness & 363.24 & 92.71 & 25.53 & 376.48 \\
\hline
\end{tabular}

The hardness values obtained for all three TMW species were lower than to untreated wood (335 kg to $672 \mathrm{~kg}$ ); values (Hill 2007). Specifically, thermally modified yellow poplar hardness was $3 \%$ to $15 \%$ lower than untreated hardness $430.9 \mathrm{~kg}$, red maple (same words, different data as YP), and ash (same words, different values). The decrease 
in hardness between the manufacturers could have been due to the different schedules used and the use of different systems (closed $v s$. open) to treat the lumber. The hardness values reported for TMW are often contradictory, with some reporting higher values and others reporting lower values (Esteves and Pereira 2009). For North American hardwoods, lower hardness values are typically found (Donahue et al. 2011; Salca and Hiziroglu 2014; Sandberg and Kutnar 2016). While many have reported lower hardness values for TMW, none have clearly identified the chemical, macro, or micro-structural changes directly responsible; only broad suggestions have been indicated, such as hardness decreases with to deterioration of the cell wall structure after the heat treatment Salca and Hiziroglu (2014). The influence of thermal modification on cell wall structure has been reviewed (Esteves and Pereira 2009). The authors' hardness results are similar to those obtained by Donahue et al. (2011), where the hardness values yellow poplar and basswood at treatment temperatures of $200{ }^{\circ} \mathrm{C}$ and $210{ }^{\circ} \mathrm{C}$, decreased from untreated values between $0 \%$ to $9 \%$ for basswood and between $38 \%$ to $54 \%$ for yellow poplar. The coefficient of variance showed higher values for company 1 and 3 for each specie studied. This could be addressed due to low amount of samples studied and high dispersion of the results obtained.

\section{Equilibrium of Moisture Content (EMC)}

There was a significant difference in the EMC values between the companies for the three species studied under the following conditions: a temperature of $21{ }^{\circ} \mathrm{C}$ and a relative humidity $(\mathrm{RH})$ of $65 \%$. The results are summarized in Table 8.

Table 8. EMC Test Results

\begin{tabular}{|c|c|c|}
\hline Test & Species & $p$-value \\
\hline EMC & Yellow poplar & 0.000 \\
\hline EMC & Red maple & 0.000 \\
\hline EMC & Ash & 0.000 \\
\hline
\end{tabular}

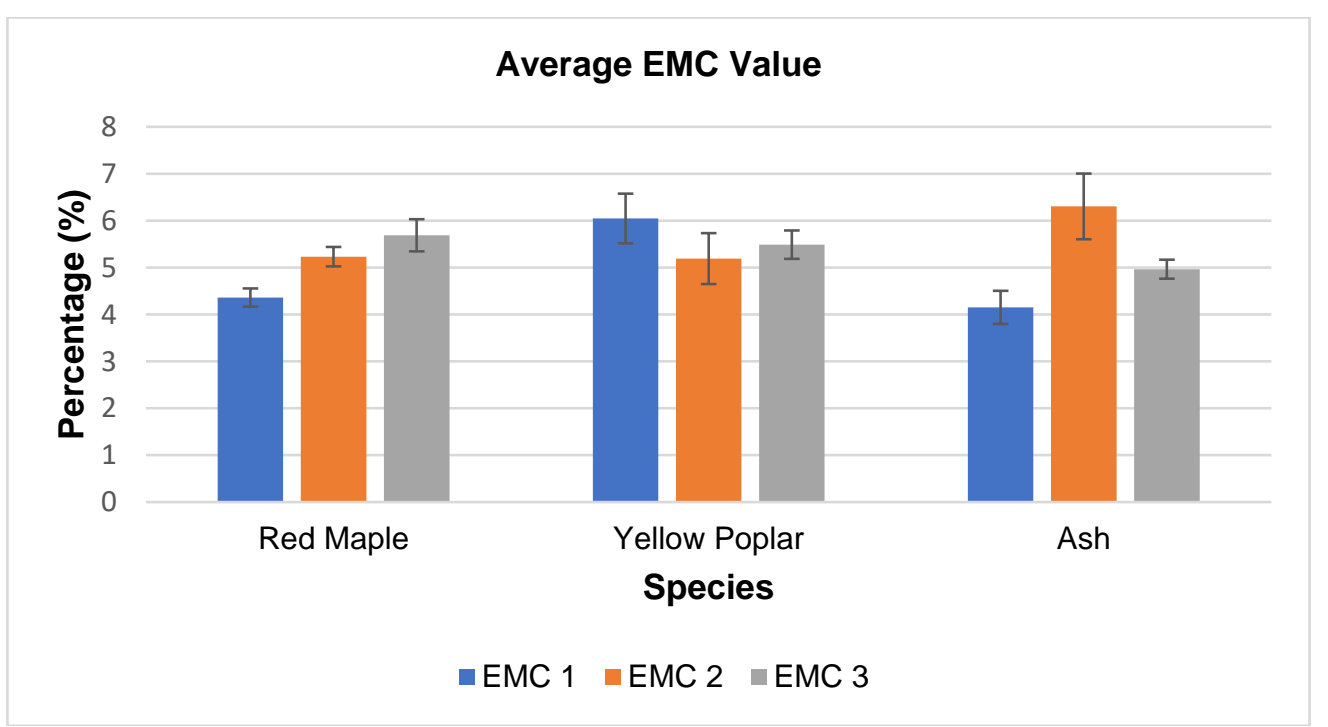

Fig. 4. Average and standard deviation for the EMC values from three companies 
Figure 4 show the interval plot and the confidence intervals for each mean. These confidence intervals showed that none of the EMC values obtained had the same mean values between companies for any of the species studied. The difference in EMC values between the companies was significant for each species, and all mean values fell withing the range of $4 \%$ to $6 \%$ (Table 9), which indicated a large reduction in EMC from unmodified wood (12\% EMC).

Table 9. Descriptive Statistics for the EMC Test Results

\begin{tabular}{|c|c|c|c|c|c|}
\hline Company & Species & Test & Mean (\%) & Std. Dev. & Median (\%) \\
\hline 1 & Yellow poplar & EMC & $6.046(\mathrm{~A})$ & 0.529 & 6.159 \\
\hline 2 & Yellow poplar & EMC & $5.191(\mathrm{~B})$ & 0.543 & 5.234 \\
\hline 3 & Yellow poplar & EMC & $5.488(\mathrm{~B})$ & 0.302 & 5.496 \\
\hline 1 & Red maple & EMC & $4.360(\mathrm{~A})$ & 0.194 & 4.317 \\
\hline 2 & Red maple & EMC & $5.232(\mathrm{~B})$ & 0.207 & 5.185 \\
\hline 3 & Red maple & EMC & $5.688(\mathrm{C})$ & 0.343 & 5.630 \\
\hline 1 & Ash & EMC & $6.303(\mathrm{~A})$ & 0.700 & 6.200 \\
\hline 2 & Ash & EMC & $4.151(\mathrm{~B})$ & 0.350 & 4.001 \\
\hline 3 & Ash & EMC & $4.934(\mathrm{C})$ & 0.228 & 4.930 \\
\hline
\end{tabular}

The EMC values from the three companies for each wood species studied showed statistically significant differences. For yellow poplar, the EMC of wood from company 1 was $15 \%$ higher than that from company 2 and $10 \%$ higher than wood from company 3 . For red maple, the EMC for wood from company 2 was $18 \%$ higher than that from company 1 and the $26 \%$ larger than that from by company 3. For ash, the EMC of wood from company 1 was $41 \%$ higher than that from company 2 and $17 \%$ higher than wood from company 3 . The results obtained showed that company 2 and company 3 tended to have similar values again, while company 1 had different values. This could be due to company 1 using an open system. In a closed system, the steam stays in the chamber, which creates pressure. An open system reduces the moisture content to $0 \%$ and eliminates steam from the chamber and then reinjects the steam to condition the wood.

While the difference in EMC values between the companies was significant for each species, all mean values fell within the range of $4 \%$ to $6 \%$ (Table 9), which indicated a large reduction in EMC from unmodified wood at $12 \% \mathrm{EMC}$, as estimated by the Hailwood-Horribin model (Simpson 1998). Simpson also stated that while the HailwoodHorribin model estimates can be influenced by hysteresis and extractive consent, they can be "considered reasonable estimates for practical applications." For example, Bond et al. (2018) found that for yellow- poplar conditioned at $20^{\circ} \mathrm{C}$ and $70 \%$ relative humidity the average EMC was $10.8 \%$, only $1.2 \%$ below the Hailwood-Horribin model.

These results showed small differences, due to the low variability between the samples and how similar the results were for each company, which were attributed to the different schedules used by the companies for each species. In treatments with a high exposure time and temperature, the EMC tended to decrease. 


\section{Dimensional Stability}

The shrinkage for the tangential sections of yellow poplar had no statistical differences, but the red maple and ash samples had statistical differences between the three companies (Table 10). For the radial section, the three species had $p$-values greater than 0.05 , meaning that there were no statistical differences between the companies.

Table 10. Dimensional Stability Test Results

\begin{tabular}{|c|c|c|}
\hline Test & Species & $p$-value \\
\hline Shrinkage-tangential & Yellow poplar & 0.356 \\
\hline Shrinkage-tangential & Red maple & $0.002^{*}$ \\
\hline Shrinkage-tangential & Ash & 0.034 \\
\hline Shrinkage-radial & Yellow poplar & 0.178 \\
\hline Shrinkage-radial & Red maple & $0.299^{*}$ \\
\hline Shrinkage-radial & Ash & $0.922^{*}$ \\
\hline $\begin{array}{l}\text { Note: an asterisk }\left(^{*}\right) \text { means that the data was not normally distributed, and a Kruskal-Wallis } \\
\text { test was conducted instead }\end{array}$
\end{tabular}

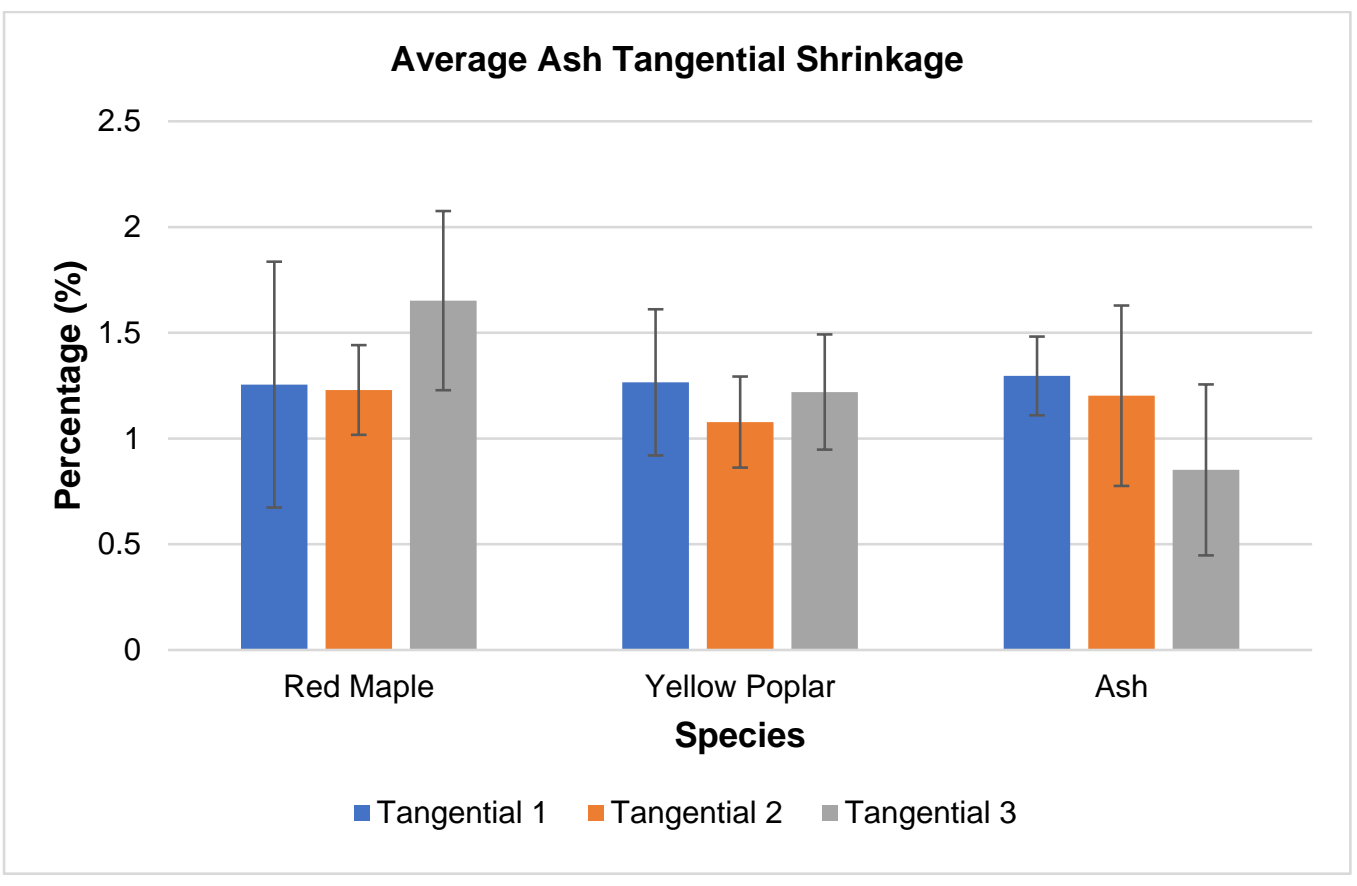

Fig. 5. Average and standard deviation for the three species' tangential shrinkage results from three companies

Figure 5 displays the Tukey analysis for the tangential section of the species studied. The results showed that company 1 had higher shrinkage values in comparison to the other two companies, and means were shared between companies 1 and 2. Table 11 shows the descriptive statistics for the dimensional stability test, which showed low standard deviation values and similar values between the mean and the median. 
Table 11. Descriptive Statistics for the Dimensional Stability Test Results

\begin{tabular}{|c|c|c|c|c|c|}
\hline Company & Species & Test & Mean (\%) & Std. Dev. & Median (\%) \\
\hline 1 & Yellow poplar & Radial shrinkage & 1.21 & 0.33 & 1.24 \\
\hline 2 & Yellow poplar & Radial shrinkage & 1.07 & 0.19 & 1.05 \\
\hline 3 & Yellow poplar & Radial shrinkage & 1.01 & 0.33 & 1.05 \\
\hline 1 & Red maple & Radial shrinkage & 1.02 & 0.28 & 1.05 \\
\hline 2 & Red maple & Radial shrinkage & 0.93 & 0.33 & 0.96 \\
\hline 3 & Red maple & Radial shrinkage & 1.17 & 0.33 & 1.02 \\
\hline 1 & Ash & Radial shrinkage & 1.11 & 0.63 & 0.97 \\
\hline 2 & Ash & Radial shrinkage & 0.87 & 0.30 & 0.78 \\
\hline 3 & Ash & Radial shrinkage & 0.97 & 0.59 & 0.73 \\
\hline 1 & Yellow poplar & Tangential shrinkage & 1.27 & 0.40 & 1.20 \\
\hline 2 & Yellow poplar & Tangential shrinkage & 1.08 & 0.10 & 1.10 \\
\hline 3 & Yellow poplar & Tangential shrinkage & 1.22 & 0.40 & 1.20 \\
\hline 1 & Red maple & Tangential shrinkage & $1.26(\mathrm{~A})$ & 0.30 & 1.10 \\
\hline 2 & Red maple & Tangential shrinkage & $1.22(\mathrm{~A})$ & 0.20 & 1.10 \\
\hline 3 & Red maple & Tangential shrinkage & $1.65(\mathrm{~B})$ & 0.30 & 1.70 \\
\hline 1 & Ash & Tangential shrinkage & $1.30(\mathrm{~A})$ & 0.58 & 1.32 \\
\hline 2 & Ash & Tangential shrinkage & $1.20(\mathrm{~B})$ & 0.21 & 1.19 \\
\hline 3 & Ash & Tangential shrinkage & $0.85(\mathrm{C})$ & 0.42 & 0.86 \\
\hline
\end{tabular}

Overall, two of the six tests conducted showed statistical differences, and the remainder showed no statistical differences, meaning the companies had similar results regarding dimensional stability performance. As mentioned in the literature review of ASTM standard D4933 (2016), dimensional stability is improved due by a decrease in equilibrium of moisture content, which primarily occurs due to a decrease of wood hygroscopicity affected by high temperatures (Dirol and Guyonnet 1993).

The dimensional stability for the tangential surface showed statistical differences for the red maple and ash samples. The difference of the tangential surface of red maple between company 1 and company 2 was 30\%, and the difference between company 1 and company 3 was $27 \%$. The difference for ash in the tangential surface between company 2 and company 3 was $34 \%$, and the difference between company 2 and company 3 was $42 \%$. For the ash values, the difference was more prominent, but when the values were compared to the untreated values, the performance was better. These improvements are discussed in the next section.

The results highlighted that the commercial processes had different schedules and technologies to thermally modify the wood. These schedules might vary between species and dimensions from each company. Sixty-one percent of the tests conducted showed that the performance of the wood samples was similar between companies.

There was a high likelihood of getting a different product from different companies, since these companies used different schedules and had different production systems, but the performance of the product between companies were practically similar. From an application perspective, the statistical differences, schedules, and systems used were not important since there was an incremental increase in dimensional stability and EMC 
performance. The yellow poplar samples showed little difference between the companies; the only difference was in the EMC values, which only varied 5\% to 6\%. This was evidence that consumers (architects) could obtain yellow poplar from any producer and expect similar performance; any difference would be so small in actuality that the consumer would not notice. The red maple samples showed statistical differences. Company 2 had a better hardness performance value, meaning that their product was better for flooring applications, and company 3 showed better performance for dimensional stability, which was better for siding applications. Regarding durability and static bending performance, red maple was not different from company to company. The ash samples showed that the MOE values for company 1 were higher, which was better for decking applications. The dimensional stability was the same for company 1 and company 2 , while the performance was lower for the tangential section of wood produced by company 3 . The performance of ash from the three companies was similar from a practical perspective. The EMC values improved from a $\mathrm{MC}$ of $12 \%$ to a $\mathrm{MC}$ of $5 \%$ for the three species, the radial shrinkage improved from a value of approximately $5 \%$ to a value of $1 \%$, while the tangential shrinkage, with values ranging from $7 \%$ to $8 \%$, improved to $1 \%$.

As demonstrated by the performance obtained from each species and company, and the commercial processes obtained from the companies studied, TMW is starting to settle into a performance baseline within the industry. Producers continue to work on optimal schedules and practices for TMW.

Future work should include looking in the performance variability within each company's processes for each species, which would allow for developing increased quality control measures. Willems et al. (2015) suggests that to obtain a reliable product, it is necessary to have quality controls. Having uniform quality control methods may increase the opportunity to achieve similar performances for the three companies and species studied.

\section{CONCLUSIONS}

1. Seven out of $18(39 \%)$ tests conducted indicated that there were statistical differences regarding the mechanical performances of the wood samples. However, from an application point of view, these differences are likely not noticeable in service, as all are a significant improvement over the properties of un-modified wood.

2. There was no difference between the hardness, MOE, and dimensional stability for yellow poplar between the three companies, indicating that the different schedules and processes resulted in in the same performance for these properties. However, the EMC for yellow poplar were significantly different between the three companies. None of the companies shared any of the mean values but, compared to the theoretical values of untreated wood, determined by the Hailwood-Horrobin equation (Simpson 1998), the values obtained for the samples provided by the three companies showed an improved performance for the EMC values. The improved performance shows that consumers can purchase TMW products from any of the producers and expect to get a product with a significant reduction in EMC.

3. The MOR, MOE, and radial shrinkage values for red maple showed no significant difference between the companies studied, indicating that the different schedules and processes resulted in in the same performance for these properties. However, there were

Gonzalez et al. (2021). "Lumber mechanical properties," BioResources 16(3), 6083-6099. 6096 
differences in hardness and tangential shrinkage values between the three companies. Company 2 had a 13 to $14 \%$ greater hardness value than company 1 . Company 1 had $27 \%$ and $30 \%$ higher tangential shrinkage values than companies 2 and 3 , respectively.

4. For white ash, there were no significant difference in values of MOR, hardness, and tangential shrinkage values. There were differences between MOE, EMC, and radial shrinkage values between the three companies, indicating that the schedule and process used influences these properties in white ash.

5. Statistical differences between the mean values for EMC and dimensional stability were found between the companies for yellow poplar, red maple, and ash. However, for all three companies, each species showed a significant reduction in both EMC and dimensional stability when compared to untreated wood values reported in the Wood Handbook (USDA, 2010).

\section{ACKNOWLEDGMENT}

Funds for this project were provided through the U.S. Forest Service Wood Innovations program.

\section{REFERENCES CITED}

Adewopo, J. B., and Patterson, D. W. (2011). "Effects of heat treatment on the mechanical properties of loblolly pine, sweetgum, and red oak," Forest Products Journal 61(7), 526-535. DOI: 10.13073/0015-7473-61.7.526

Alén, R., Kotilainen, R., and Zaman, A. (2002). "Thermochemical behavior of Norway spruce (Picea abies) at 180-225 ${ }^{\circ} \mathrm{C}$, , Wood Science and Technology 36, 163-171. DOI: $10.1007 / \mathrm{s} 00226-001-0133-1$

ASTM D143-14 (2014). "Standard test methods for small clear specimens of timber," ASTM International, West Conshohocken, PA.

ASTM D4442-16 (2016). "Standard test methods for direct moisture content measurement of wood and wood-based materials," ASTM International, West Conshohocken, PA.

ASTM D4933-16 (2016). "Standard guide for moisture conditioning of wood and woodbased materials," ASTM International, West Conshohocken, PA.

Baynes, J., Herbohn, J., Gregorio, N., and Fernandez, J. (2014). "How useful are small stands of low-quality timber?," Small-scale Forestry 14(2), 193-204. DOI:10.1007/s11842-014-9281-7.

Bond, B. H., Durgante-Severo, E., Fernanda, A., and Williams, F. (2018). "Influence of thermal modification on selected properties of yellow-poplar," in: 2018 Forest Products Society, International Convention, Madison, WI.

Boonstra, M. J., Van Acker, J., Tjeerdsma, B. F., and Kebel, E. V. (2007). "Strength properties of thermally modified softwoods and its relation to polymeric structural wood constituents," Ann. For. Sci. 64, 679-690. DOI: 10.1051/forest:2007048

CEN. (2007). "Thermal modified timber - Definitions and characteristics," (Vol. Technical specification no. CEN/TS 15679, pp. 22). Brussels, Belgium: European Committee for Standardization (CEN). 
Dirol, D., and Guyonnet, R. (1993, May). "The improvement of wood durability by retification process," in: The international research group on wood preservation _ Section 4 _ Report prepared for the 24 Annual Meeting (pp. 1-11).

Donahue, P., Aro, M., French-Coda, S., and Chen, W. (2011). Thermally-Modified Eastern Hardwoods as High-Tech Fenestration and Exterior Shuttering (Project No. 09-DG-090), USDA Wood Education and Resource Center, Princeton, WV.

Donahue, P., and Winandy, J. E. (2014). "Development and use of AWPA/ANSI Guidance Document N--Data requirements for listing thermally modified wood in AWPA standards," Technical Session: Wood Thermal Modification: Technical Updates and Opportunities for Collaboration.

EPH. (2015). Quality Mark TMT (pp. 10). Dresden, Germany.

Esteves, B., and Pereira, H. (2008). "Wood modification by heat treatment: A review," BioResources 4(1), 370-404. DOI: 10.15376/biores.4.1.370-404

Gamache, S. (2017). Professional Consumer Perceptions of Thermally-Modified Wood, Master's Thesis, University of Minnesota, Minneapolis, MN.

Ghiassi, B., and Lourenço, P. B. (2018). Long-term Performance and Durability of Masonry Structures: Degradation Mechanisms, Health Monitoring and Service Life Design, Woodhead Publishing, Sawston, United Kingdom.

Hill, C. A. S. (2007). Wood Modification: Chemical, Thermal, and Other Processes (Vol. 5), John Wiley and Sons, Hoboken, NJ.

Odoom, F. (2001). "Promotion of valuable hardwood plantations in the tropics. A global overview," Forest Plantations Thematic Papers 4, 1-21.

Sandberg, D., and Kutnar, A. (2016). "Thermally modified timber: recent developments in Europe and North America," Wood and Fiber Science 48, 28-39.

Salca, E.-A. and Hiziroglu, S. (2014). "Evaluation of hardness and surface quality of different wood species as function of heat treatment," Materials and Design 62, 416423. DOI: 10.1016/j.matdes.2014.05.029

Schnabel, T., Zimmer, B., Petutschnigg, A. J., and Schönberger, S. (2007). “An approach to classify thermally modified hardwoods by color," Forest Products Journal 57(9), 105-110.

Simpson, W. T. (1998). "Equilibrium moisture content of wood in outdoor locations in the United States and worldwide," Res. Note FPL-RN-0268. Madison, WI: U.S. Department of Agriculture, Forest Service, Forest Products Laboratory. 11 p. DOI: 10.2737/FPL-RN-268

USDA, Forest Service, Forest Products Laboratory (2010). Wood Handbook: Wood as an Engineering Material, Madison, WI, U.S. Dept. of Agriculture, Forest Service, Forest Products Laboratory.

Wang, W., Cao, J., Cui, F., and Wang, X. (2012). "Effect of pH on chemical components and mechanical properties of thermally modified wood," Wood and Fiber Science 44(1), 46-53.

Wardell, C. (2015). "Thermally modified decking," (https://www.deckmagazine.com/design-construction/decking/thermally-modifieddecking_o), Accessed on May 30, 2020.

Willeitner, H. (2012). "Einführung in den Themenblock DIN 68800-Spannungsfeld durch neue Richtlinien-Möglichkeiten und Grenzen," Deutsche Holzschutztagung: Trends und Chancen. 
Willems, W., Lykidis, C., Altgen, M., and Clauder, L. (2015). "Quality control methods for thermally modified wood," Holzforschung 69(7), 875-884. DOI: 10.1515/hf-20140185

Article submitted: September 24, 2020; Peer review completed: October 31, 2020; Revised version received and accepted: July 13, 2021; Published: July 19, 2021.

DOI: 10.15376/biores.16.3.6083-6099 